\title{
PENGAWETAN KAYU KARET (Hevea brasiliensis) DAN KAYU KOPI (Coffea sp.) DENGAN BROTOWALI (Tinospora crispa)
}

\author{
Rubber (Hevea brasiliensis) and Coffee (Coffea sp.) Wood Preservation with Brotowali \\ (Tinospora crispa)
}
Istihanah Nurul Eskani, Guring Briegel Mandegani, I Made Arya Utamaningrat, dan Agung Eko Sucahyono
Balai Besar Kerajinan dan Batik, Kementerian Perindustrian, Jalan Kusumanegara no. 7, Yogyakarta

Korenspondesi Penulis

Email :gbmandegani@gmail.com
Naskah Masuk : 31 Desember 2019

Revisi : 21 September 2020

Disetujui : : 28 September 2020

Kata kunci: kayu karet, kayu kopi, pengawetan

Keywords: wood, Hevea brasiliensis, Coffea sp., preservation

\begin{abstract}
ABSTRAK
Pohon karet (Hevea brasiliensis) dan kopi (Coffea sp.) merupakan tanaman perkebunan yang dibudidayakan di Indonesia. Kayu karet lemah terhadap serangan kutu dan jamur blue stain. Pohon karet dan kopi mempunyai karakteristik kelas kuat II-III, dan kelas awet IV-V. Menurut SNI 03-5010.11999, kayu dengan kelas kuat III- IV-V dan kelas awet III-IV-V harus dilakukan pengawetan untuk menambah umur kayu. Kegiatan ini bertujuan untuk mengetahui kinerja brotowali (Tinospora cordifolia) sebagai pengawet alami pada kayu karet dan kopi sekaligus memanfaatkan kayu karet sebagai bahan baku mebel. Kayu karet dan kopi diberikan perlakuan dengan larutan brotowali 2,5\%, $5 \%$ dan 7,5\% dengan durasi lama perendaman kayu 1, 2 dan 3 minggu. Perbedaan perlakuan memberikan hasil yang berbeda, retensi pada kayu berbanding lurus dengan lama perendaman dan konsentrasi. Pengujian ketahanan rayap pada hasil proses pengawetan, memberikan hasil yang positif, dengan nilai mortalitas mencapai $100 \%$. Brotowali dapat memberikan hasil pengawetan yang baik dengan komposisi larutan terbaik 7,5\% selama 3 minggu.
\end{abstract}

\section{ABSTRACT}

Rubber trees (Hevea brasiliensis) and coffee (Coffea sp.) are plants that have been cultivated in Indonesia. Rubber and coffee trees have wood strength at category III-IV and it has durability at category IV-V. Rubberwood is weak against termites and blue stain fungus. According to SNI 035010.1-1999, wood with category III-IV-V of strength and category III-IV-V of durability have to be preserved to prolong the age of the wood. The aim of the study was to evaluate the perfomance of Brotowali as a natural preservative in rubberwood and coffee wood while also using it as raw material for furniture. Rubberwood and coffee treated with 2.5\%,5\%, and $7.5 \%$ solutions with the duration of soaking wood are 1, 2, and 3 weeks. The treatment gives different results; retention in wood is directly proportional to the soaking time and concentration. Termite endurance testing on the results of the preservation process, gave positive results, with a mortality value reaching $100 \%$. Brotowali can provide good preservation results with the best composition of a $7.5 \%$ solution. 
clKh Dinamika Kerajinan dan Batik: Majalah Ilmiah. Vol. 37 No. 2, Desember 2020, Hal. 185 - 194

\section{PENDAHULUAN}

Indonesia kaya dengan sumber daya alam yang dapat dimanfaatkan sebagai bahan baku untuk memenuhi kebutuhan masyarakat. Salah satu potensi sumber daya alam Indonesia adalah produk hutan kayu dan non kayu (Badan Pusat Statistik Indonesia, 2019b). Produk kayu dan non kayu banyak dimanfaatkan sebagai produk mebel, konstruksi, papan serat, papan partikel, ataupun bahan lain seperti pembuatan arang. Produk kayu sebagai bahan mebel ataupun konstruksi didapatkan dari berbagai jenis kayu di Indonesia seperti kayu jati (Tectona grandis.), akasia (Acacia sp.), meranti (Shorea sp.), sengon (Albizia chinensis), pinus (Pinus sp.), tusam/karet (Hevea brasiliensis), merbau (Intsia bijuga), dan lain sebagainya.

Salah satu jenis kayu yang dimanfaatkan adalah kayu karet yang banyak tumbuh di Indonesia. Menurut data BPS tahun 2018, luas perkebunan karet di Indonesia sebesar 3.549.044 $\mathrm{Ha}$ dan potensi area yang menghasilkan sejumlah 3.047.978 $\mathrm{Ha}$ dengan total nilai produksi kayu karet mencapai 176,652 $\mathrm{m}^{3}$ kayu bulat (Badan Pusat Statistik Indonesia, 2019a).

Perkebunan karet memiliki potensi kayu yang cukup besar, yakni sebesar 500-600 pohon per hektar (Lasminingsih, 2014). Mengacu pada data BPS tentang Statistik Karet Indonesia pada tahun 2018, terdapat potensi 83 ribu hektar tanaman karet yang tidak menghasilkan (Badan Pusat Statistik Indonesia, 2019a). Dengan jumlah tersebut, ada potensi lebih dari 40 juta batang yang dapat dimanfaatkan secara bertahap tergantung pada umur kayu karet. Salah satu pemanfaatan kayu karet adalah sebagai bahan baku barang kerajinan ataupun barang mebel dengan kapasitas kecil.

Tabel 1. Luas perkebunan karet di Indonesia (ribu Ha) (Badan Pusat Statistik Indonesia, 2019a)

\begin{tabular}{ccccc}
\hline & 2015 & 2016 & 2017 & 2018 \\
\hline PBN & 230,17 & 230,65 & 233,09 & 189,58 \\
\hline PBS & 315,31 & 316,03 & 322,73 & 246,05 \\
\hline PR & $3.075,63$ & $3.092,37$ & $3.103,31$ & $3.113,42$ \\
\hline Total & $3.621,11$ & $3.639,05$ & $3.659,13$ & $3.549,04$ \\
\hline
\end{tabular}

Keterangan :

PBN : Perkebunan Besar Negara

PBS : Perkebuanan Besar Swasta

PR : Perkebunan Rakyat

\section{Karet (Hevea brasiliensis)}

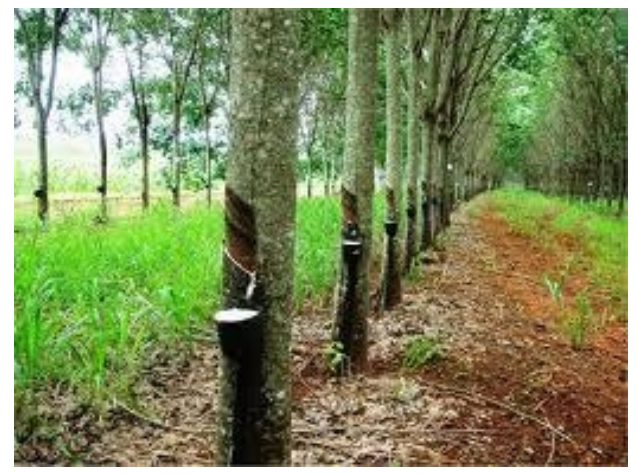

Gambar 1. Pohon karet

(sumber: http://www.pustakapetani.com/ 2018/03/syarat-tumbuh- tanaman-karet.html)

(Pustaka Petani, 2018)

Pohon karet merupakan salah satu tanaman perkebunan dengan nilai ekonomi tinggi. Hasil pohon karet berupa getah karet yang dapat disadap mulai tahun ke-5. Getah tersebut dapat digunakan menjadi lembaran karet (sheet), bongkahan (kotak) atau karet remah (crumb rubber). Pohon karet perlu diremajakan pada umur tertentu sehingga akan menghasilkan kayu yang dapat dibuat untuk bahan konstruksi 
clKh Dinamika Kerajinan dan Batik: Majalah Ilmiah. Vol. 37 No. 2, Desember 2020, hal. 185 - 194

ataupun lainnya. Pohon karet pada dasarnya merupakan kayu kualitas menengah. Kayu karet memiliki kelas kuat II-III dan kelas awet IV-V (Suheryanto, 2010).

\section{Kopi (Coffea sp.)}

Kopi merupakan tanaman perkebunan yang sudah banyak dibudidayakan. Kopi merupakan tanaman yang berbentuk semak termasuk dalam famili Rubiceae dan genus Coffea. Tanaman ini tumbuhnya tegak, bercabang, mampu mencapai tinggi $12 \mathrm{~m}$. Bentuk daunnya bulat telur dengan ujung agak meruncing, tumbuh berhadapan pada batang, cabang, dan ranting-rantingnya (Najiyati \& Danarti, 1990).

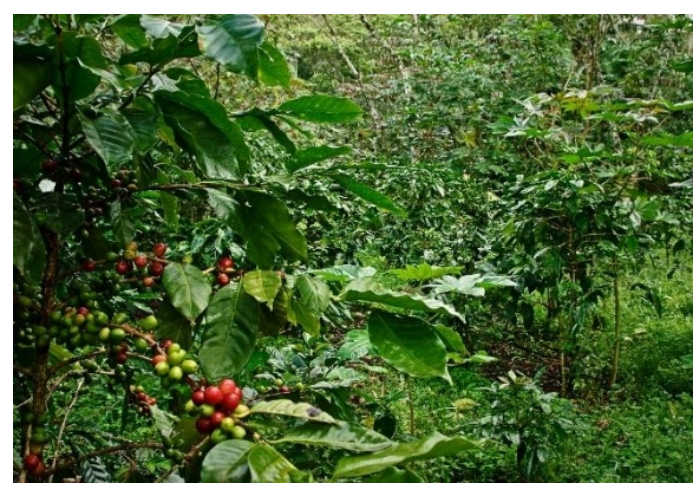

Gambar 2. Tanaman kopi

(sumber : https://majalah.ottencoffee.co.id/kopiyang-tumbuh-di-bawah-naungan-pohonsebagus-apa/)(Masdakaty, 2016)

Kopi merupakan tanaman semak belukar yang termasuk ke dalam genus Coffea. Genus Coffea memililki sekitar 66 spesies. Dari sekian banyak spesies, hanya 4 jenis kopi yang dibudidayakan diantaranya yakni kopi robusta (Coffea canephora), kopi arabika (Coffea arabica), kopi excelsa (Coffea excelsa) dan kopi liberica (Coffea liberica) (Rochim, 2017).

Tanaman kopi merupakan tanaman yang banyak dibudidayakan di Indonesia.
Data luas perkebunan kopi di Indonesia ditunjukkan pada tabel 2.

Tabel 2 Luas perkebunan kopi di Indonesia ( $\mathrm{Ha})$ (Badan Pusat Statistik Indonesia, 2018)

\begin{tabular}{ccc}
\hline & Tahun 2017 & Tahun 2018 \\
\hline TBM & 179.913 & 180.773 \\
\hline TM & 926.441 & 920.276 \\
\hline TBM & 132.110 & 134.700 \\
\hline Total & 1.238 .466 & 1.235 .799 \\
\hline
\end{tabular}

Keterangan :

TBM : Tanaman Belum Menghasilkan

TM : Tanaman Menghasilkan

TTM : Tanaman Tidak Menghasilkan

Tanaman kopi dalam 1 hektar memiliki jumlah 1000 buah (Mahfud, Nurbanah, Ismiyati, \& Ardiansyah, 2010), dengan jumlah tersebut, akan ada potensi pemanfaatan sejumlah 130 juta pohon kopi untuk diolah lebih lanjut. Kayu kopi digunakan olah masyarakat Jawa Timur untuk produk kerajinan seperti stik drum, tasbih, tempat golok, furnitur (Hisyam, Suharso, \& Widodo, 2015) dan kacamata (Dorojati \& Kuswanto, 2018). Selain itu, kayu kopi telah diujicoba untuk pembuatan produk kreatif lainnya yakni produk kap lampu dan mini amplifier (Rochim, 2017).

\section{Pengawetan}

Pengawetan kayu merupakan cara untuk mempertahankan kayu dari kondisi yang mampu merusak kayu. Kondisi tersebut disebabkan oleh cuaca ataupun organisme. Pengawetan dilakukan dengan memasukkan bahan kimia alami maupun sintetis ke dalam kayu untuk meningkatkan kelas awetnya. Bahan pengawet yang banyak digunakan adalah bahan-bahan kimia yang akan menyebabkan kayu menjadi tahan terhadap serangan faktor 
perusak kayu. Berdasarkan sifat fisik dan kimia, pengawet dapat digolongkan menjadi pengawet berbahan minyak, pengawet larut minyak, dan pengawet larut air (Rachmat, 2007). Kayu karet dengan kelas awet IV-V perlu dilakukan pengawetan agar menambah ketahanan kayu dari kerusakan.

Penggunaan pengawet secara alami dapat diperoleh dengan cara mengekstrak dari bagian tumbuh-tumbuhan seperti kayu, biji, daun, dan bunga (Arif, Usman, \& Samma, 2007). Salah satu tanaman dengan kemampuan pengawet alami adalah Tinospora crispa atau yang biasa dikenal dengan nama brotowali (Wiratno, Nurhayati, \& Sujianto, 2019). Tanaman brotowali merupakan tanaman semak dengan jumlah yang melimpah dan memiliki kandungan senyawa alkaloid, damar lunak, pati, glikosida, pikroretosid, harsa, zat pahit pikroretin, tinokrisposid, berberin, palmatin, kolumbin, dan kaokulin atau pikrotoksin (Kresnady, 2003). Brotowali dapat digunakan sebagai insektisida alami karena mengandung alkaloid, tinokrisposid, dan glikosida (Dumeva, Syarifah, \& Fitriah, 2016). Salah satu penggunaan sebagai insektisida alami yakni pengendalian tungau dan lintah (de Boer, Vongsombath, Pålsson, Björk, \& Jaenson, 2010), pengendalian Nephotetix dan Nilaparvata lugens, serta serangga Plutella xylostella (Isa et al., 2013). Berdasarkan kandungan bahan aktif tanaman brotowali, ada potensi pengembangan sebagai bahan insektisida, fungisida, nematisida dan moluscicida (Wiratno et al., 2019).

Tujuan dari penelitian ini adalah untuk mengetahui kinerja brotowali sebagai pengawet alami pada kayu karet dan kopi sebagai bahan baku furnitur.

\section{METODOLOGI PENELITIAN}

\section{Bahan dan Alat}

Bahan yang digunakan dalam kegiatan ini adalah kayu karet kering yang didapatkan dari Kecamatan Piyungan, Kabupaten Bantul, kayu kopi kering dari kawasan perkebunan Kecamatan Sentolo Kabupaten Kulon Progo, dan bubuk brotowali dari pasar Beringharjo, Kota Yogyakarta. Peralatan yang digunakan antara lain gergaji belah, gergaji crosscut (miter saw), mesin serut, timbangan elektronik, bak perendaman kayu, gelas ukur, pengaduk kayu, kaliper, penggaris dan alat pengukur kadar air digital.

Penelitian dilaksanakan di Laboratorium Kayu, Rotan dan Bambu Balai Besar Kerajinan dan Batik, Yogyakarta pada bulan Juni-Agustus 2018.

\section{Prosedur Kerja}

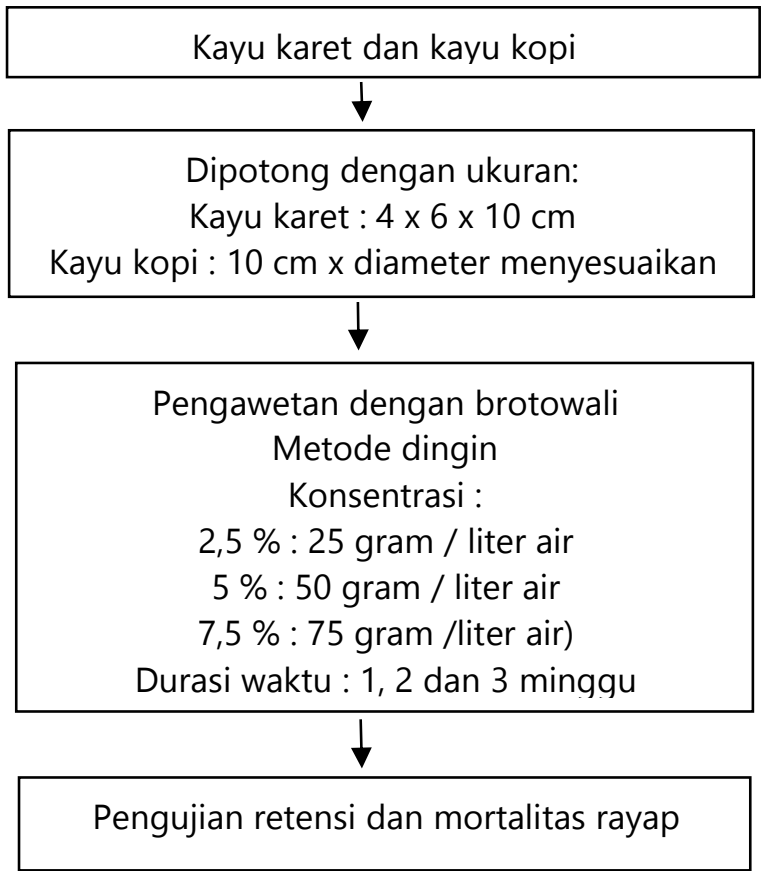

Gambar 1. Metode penelitian 
clKh Dinamika Kerajinan dan Batik: Majalah Ilmiah. Vol. 37 No. 2, Desember 2020, hal. 185 - 194

Preparasi Sampel

Sampel dibuat dengan cara memotong batang pohon karet dan kopi menjadi bentuk balok dengan ukuran $4 \mathrm{~cm} \times 6 \mathrm{~cm} \times$ $10 \mathrm{~cm}$, sementara sampel kayu kopi dipotong dengan panjang $10 \mathrm{~cm}$ dan bentuk sesuai dengan penampang masing masing batang (diameter dan bentuk dapat berbeda).

Setelah sampel dipotong sesuai bentuk dan ukuran, kedua jenis sampel kayu kemudian dibiarkan dalam ruangan hingga kadar airnya berkurang. Kadar air pada sampel diukur secara berkala dengan menggunakan alat pengukur kadar air digital. Setelah kadar air sampel mencapai nilai di bawah 20\%, sampel siap untuk diawetkan.

\section{Preparasi Pengawet}

Pengawet yang digunakan dibuat dengan cara mencampurkan 25, 50 dan 75 gram serbuk brotowali masing-masing ke dalam 1 liter air sumur.

Ekstraksi brotowali dilakukan dengan pemanasan pada temperatur $\pm 80^{\circ} \mathrm{C}$ selama 180 menit. Setelah proses ekstraksi selesai, ekstrak didinginkan hingga tercapai temperatur ruang, kemudian disaring dan dituang ke dalam wadah.

\section{Pengawetan}

Sampel kayu direndam dalam ekstrak brotowali dengan konsentrasi 2,5\%,5\%, dan $7,5 \%$ dengan variasi durasi selama 1, 2 dan 3 minggu.

\section{Pengujian Retensi}

Retensi dilakukan untuk mengetahui jumlah bahan pengawet yang masuk ke dalam kayu. Nilai retensi dihitung menggunakan rumus berikut:

$$
R=\frac{B_{1}-B_{0}}{V} \times K \quad \text { (Rachmat, 2007) }
$$

Keterangan :

$\mathrm{R}$ : nilai retensi zat pengawet $\left(\mathrm{kg} / \mathrm{m}^{3}\right)$

$B_{1}$ : berat spesimen uji setelah pengawetan $(\mathrm{kg})$

$B_{0}$ : berat spesimen uji sebelum pengawetan $(\mathrm{kg})$

$\mathrm{V}$ : volume spesimen uji $\left(\mathrm{m}^{3}\right)$

$\mathrm{K}$ : konsentrasi larutan pengawet $(\mathrm{g} / \mathrm{l})$

\section{Pengujian Mortalitas Rayap}

Pengujian mortalitas rayap dilakukan untuk mengetahui efektivitas ketahanan pengawet pada kayu sampel terhadap rayap. Pengujian ini dilakukan di Laboratorium Teknik Kehutanan Universitas Gadjah Mada dengan acuan SNI 01-7207-2006 tentang Uji ketahanan kayu dan produk kayu terhadap organisme perusak kayu. Pengujian dilakukan dengan cara melapisi kayu hasil pengawetan dengan aluminium berukuran $7 \mathrm{~cm} \times 5 \mathrm{~cm}$ yang sudah dilubangi sebanyak 10 lubang. Pada masing-masing lubang kemudian dimasukkan 1 larva bubuk berumur 6 minggu yang sehat dan aktif. Kemudian contoh uji diletakkan pada cawan petri dan disimpan dalam ruangan gelap dengan suhu $25^{\circ} \mathrm{C} \pm 5^{\circ} \mathrm{C}$ dengan kelembaban $70 \%$. Pengamatan dilakukan selama 6 minggu untuk melihat mortalitas dan intensitas serangan larva.

\section{HASIL DAN PEMBAHASAN}

Efektivitas pengawetan dapat diketahui dari nilai retensi yang merupakan banyaknya bahan pengawet kering (tanpa pelarut) yang meresap dan tertinggal di dalam kayu yang diawetkan. Semakin tinggi retensi bahan pengawet, maka efek perlindungan bahan pengawet pada kayu 
clKh Dinamika Kerajinan dan Batik: Majalah Ilmiah. Vol. 37 No. 2, Desember 2020, hal. 185 - 194

terhadap organisme perusak kayu akan semakin baik (Kusumaningsih, 2011). SNI 03-5010.1-1999 tentang Pengawetan kayu untuk perumahan dan gedung mempersyaratkan kualitas pengawetan kayu untuk penggunaan interior (dalam ruangan bawah atap) memiliki retensi minimal $8 \mathrm{~kg} / \mathrm{m}^{3}$, sedangkan retensi minimal untuk kondisi eksterior (luar ruangan) adalah 11 $\mathrm{kg} / \mathrm{m}^{3}$.

Kayu karet dan kopi dengan perlakuan pengawetan, menunjukkan nilai retensi seperti yang ditunjukkan pada Gambar 2. Dari gambar 2 dapat diketahui bahwa kayu karet dengan konsentrasi pengawet 2,5\% memiliki retensi yang relatif rendah. Nilai retensi mengalami peningkatan seiring dengan semakin lamanya durasi pengawetan. Akan tetapi hingga minggu ketiga perendaman nilai retensi belum memenuhi persyaratan pada SNI 03-5010.11999 sehingga belum layak untuk digunakan sebagai bahan interior maupun eksterior.

Kayu karet dengan konsentrasi pengawet $5 \%$ dapat memenuhi nilai retensi minimal yang disyaratkan SNI 03-5010.11999 untuk penggunaan interior setelah perendaman selama 1 minggu. Pada minggu kedua perendaman, terjadi peningkatan nilai retensi sehingga dapat memenuhi syarat SNI 03-5010.1-1999 baik untuk produk interior maupun eksterior.

Pada konsentrasi pengawet 7,5\%, nilai retensi pada perendaman 1 minggu sudah mencapai syarat minimal untuk interior dan eksterior (nilai retensi $12,03 \mathrm{~kg} / \mathrm{m}^{3}$ ). Nilai retensi bertambah menjadi 2 kali lipat pada perendaman selama 2 minggu (mencapai $23,6 \mathrm{~kg} / \mathrm{m}^{3}$ ). Pada minggu ketiga kembali terjadi peningkatan meskipun tidak signifikan. Hal ini menunjukkan bahwa durasi pengawetan mempengaruhi nilai retensi kayu, yakni semakin lama durasi perendaman, bahan pengawet mempunyai waktu yang lebih lama untuk meresap. Jumlah bahan pengawet yang masuk ke dalam kayu dipengaruhi oleh sifat fisika, sifat kimia dan struktur anatomi kayu tersebut (Wahyudi, 2013)

Pada Gambar 2 terlihat bahwa nilai retensi pada kayu kopi dengan konsentrasi pengawet brotowali 2,5\% masih belum memenuhi syarat minimal SNI hingga minggu ketiga perendaman. Jika dilakukan perendaman lebih lama, nilai retensi kemungkinan masih dapat meningkat. Pada larutan pengawet dengan konsentrasi 5\% dan $7,5 \%$, nilai retensi sudah memenuhi syarat minimal SNI untuk produk interior maupun eksterior karena pada 1 minggu perendaman dengan nilai retensi masingmasing $16,2 \mathrm{~kg} / \mathrm{m}^{3}$ dan $28,5 \mathrm{~kg} / \mathrm{m}^{3}$.

Nilai retensi yang didapat oleh kayu kopi lebih besar daripada kayu karet. Nilai ini disebabkan oleh kemampuan serap dan struktur anatomi dari kayu yang berbeda. Kayu kopi memiliki karakter bentuk yang lebih ramping (diameter batang $\pm 4 \mathrm{~cm}$ ) dibandingkan dengan kayu karet (diameter batang $\pm 20 \mathrm{~cm}$ ). Selain itu, kandungan getah pada kayu karet yang masih ada, berpotensi mempengaruhi daya serap bahan pengawet. (Suriani, 2018).

\section{Nilai mortalitas}

Pengujian mortalitas rayap hanya dilakukan pada kayu karet. Sedangkan pada kayu kopi tidak dilakukan karena kondisi kayu kopi yang relatif kecil (diameter bervariasi $3-5 \mathrm{~cm}$ ), dengan bentuk batang 
clKh Dinamika Kerajinan dan Batik: Majalah Ilmiah. Vol. 37 No. 2, Desember 2020, hal. 185 - 204

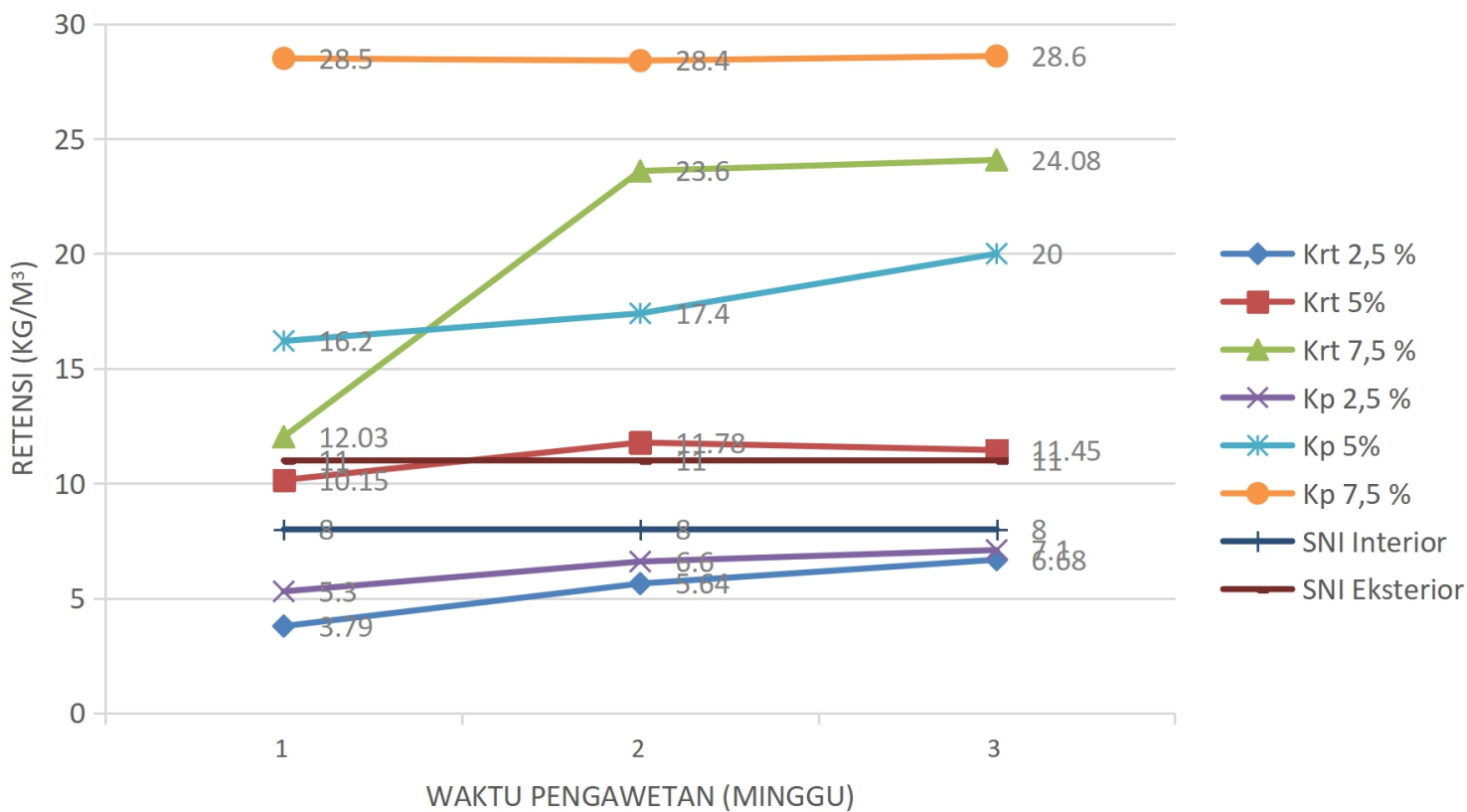

Keterangan: Krt = kayu karet, Ko = kayu kopi. Kode angka menunjukkan persentase brotowali yang digunakan dalam pengawetan kayu.

Gambar 2. Retensi kayu karet dan kayu kopi yang diawetkan dengan beberapa konsentrasi brotowali selama 3 minggu.

yang bervariasi, sehingga preparasi sampel untuk uji mortalitas sulit dilakukan.

Kayu karet dengan pengawetan brotowali memiliki ketahanan rayap yang cukup baik. Dari Tabel 3, diketahui bahwa nilai maksimal mortalitas rayap yang diperoleh adalah 100\%. Akan tetapi, terdapat perbedaan nilai mortalitas untuk tiap perlakuan yang berbeda. Dimungkinkan ada beberapa hal yang mempengaruhi perbedaan hasil tersebut, antara lain sifat kanibalisme pada rayap sehingga memungkinkan rayap mati karena saling serang pada waktu sumber makan terbatas (Hutabarat, Oemry, \& Pinem, 2015). Hal lain yang memungkinkan adalah rayap yang memakan kayu sebenarnya dapat bertahan beberapa hari karena perbedaan kerataan penetrasi zat pengawet. Namun secara umum, nilai mortalitas rayap yang didapatkan masih cukup baik.

Tabel 3. Nilai persentase mortalitas rayap pada kayu karet (Rata-rata dan maksimal)

\begin{tabular}{ccccc}
\multirow{2}{*}{$\begin{array}{c}\text { Konsentrasi } \\
\text { Larutan }\end{array}$} & \multicolumn{4}{c}{ Lama perendaman (minggu) } \\
\cline { 2 - 5 } Kontrol & 74 & & $\mathbf{2}$ & $\mathbf{3}$ \\
\hline $2,5 \%$ & $\begin{array}{c}\text { rata- } \\
\text { rata }\end{array}$ & 16,67 & 49,33 & 51,33 \\
\hline 5 & maks & 22 & 100 & 78 \\
\hline $5 \%$ & $\begin{array}{r}\text { rata- } \\
\text { rata }\end{array}$ & 42,67 & 53 & 44,67 \\
\hline $7,5 \%$ & maks & 70 & 100 & 50 \\
\hline & $\begin{array}{c}\text { rata- } \\
\text { rata }\end{array}$ & 60,67 & 66 & 34,67 \\
\hline & maks & 100 & 88 & 50
\end{tabular}


clKh Dinamika Kerajinan dan Batik: Majalah Ilmiah. Vol. 37 No. 2, Desember 2020, hal. 185 - 194

\section{KESIMPULAN DAN SARAN}

Kesimpulan

Kayu karet dan kayu kopi dengan perlakuan pengawetan larutan brotowali memenuhi salah satu syarat retensi untuk dapat dimanfaatkan sebagai bahan baku olahan kayu seperti furnitur maupun kerajinan baik interior maupun eksterior. Namun masih perlu pemrosesan kayu lebih lanjut seperti pemilihan pengawetan dan proses finishing untuk mendapatkan kualitas yang lebih baik.

\section{Saran}

Perlu dilakukan penelitian lebih lanjut dengan penambahan variasi konsentrasi atau durasi untuk mendapatkan kondisi optimum.

\section{KONTRIBUSI PENULIS}

Semua penulis merupakan kontributor dengan kapasitas yang sama.

\section{UCAPAN TERIMA KASIH}

Terima kasih kepada Balai Besar Kerajinan dan Batik atas kesempatan dan pendanaan kegiatan penelitian pemanfaatan kayu karet dan kopi.

\section{DAFTAR PUSTAKA}

Arif, A., Usman, M. N., \& Samma, F. (2007). Sifat Anti Rayap dari Ekstrak Ijuk Aren (Arenga pinnata Merr.). Perennial, 3(1), 15. https://doi.org/10.24259/perennial.v3i1.16 5

Badan Pusat Statistik Indonesia. (2018). Statistik Kopi Indonesia 2018. Jakarta.

Badan Pusat Statistik Indonesia. (2019a). Statistik Karet Indonesia 2018. Jakarta.

Badan Pusat Statistik Indonesia. (2019b). Statistik Produksi Kehutanan 2018. Jakarta.

de Boer, H., Vongsombath, C., Pålsson, K., Björk, L., \& Jaenson, T. G. T. (2010). Botanical Repellents and Pesticides Traditionally Used Against Hematophagous
Invertebrates in Lao People's Democratic Republic: A Comparative Study of Plants Used in 66 Villages. Journal of Medical Entomology, 47(3), 400-414. https://doi.org/10.1603/ME09273

Dorojati, M., \& Kuswanto, D. (2018). Desain Kacamata Kayu Memanfaatkan Kayu Kopi Robusta Jawa Timur dengan Konsep Diver. Tugas Akhir. Fakultas Teknik Sipil dan Perencanaan. Institut Teknologi Sepuluh November. Surabaya.

Dumeva, A., Syarifah, \& Fitriah, S. (2016). Pengaruh Ekstrak Batang Brotowali (Tinospora crispa) Terhadap Kematian Larva Nyamuk Aedes aegypti. Biota, 2(2), 166-172.

Hisyam, A., Suharso, P., \& Widodo, J. (2015). Pemberdayaan Masyarakat Berbasi Ekonomi Kreatif Melalui Pelatihan Pembuatan Produk Hiasan Dari Limbah Pohon Kopi ( Studi Kasus Pada Masyarakat Miskin Perkebunan Kopi Di Desa Harjomulyo Kecamatan Silo Kabupaten Jember).

Hutabarat, N. K., Oemry, S., \& Pinem, M. I. (2015). Uji Efektivitas Termitisida Nabati Terhadap Mortaliatas Rayap (Coptotermes curvinagthus Holmgren) (Isoptera: Rhinotermitidae) di Laboratorium. Jurnal Online Agroekoteknologi, 8(2337), 103111.

Isa, N., Aziz Satar, S., Bakhari, N. A., Fadzilah, S. N. A. D., Boon Tik, L., \& Wan Kamaruddin, W. Z. (2013). The effect of Tinospora crispa extract against Spodoptera exigua on Spinacia oleracea. Malaysian Journal of Fundamental and Applied Sciences, 9(2). https://doi.org/10.11113/mjfas.v9n2.93

Kresnady. (2003). Khasiat dan Manfaat Brotowali. Jakarta: Agro Media Pustaka.

Kusumaningsih, K. R. (2011). Sifat Penyerapan Bahan Pengawet Pada Beberapa Jenis Kayu Bangunan. Jurnal Wana Tropika, 1(1), 1625.

Lasminingsih, M. (2014). Pedoman Budidaya Karet yang Baik (M. Astuti, Hafiza, E. Yuningsih, A. R. Wasingun, I. M. Nasution, \& D. Mustikawati, Eds.). Direktorat Jendral Perkebunan, Kementrian Pertanian.

Mahfud, M. C., Nurbanah, S., Ismiyati, \& Ardiansyah. (2010). Kajian Penerapan Teknologi Produksi Pada Usaha Tani Kopi 
clKh Dinamika Kerajinan dan Batik: Majalah Ilmiah. Vol. 37 No. 2, Desember 2020, hal. 185 - 194

Robusta Di Lokasi Prima Tani Kabupaten Pasuruan. Jurnal Pengkajian Dan Pengembangan Teknologi Pertanian, 13(3), 141-147. https://doi.org/10.21082/jpptp.v13n2.2010. $\mathrm{p}$

Masdakaty, Y. (2016). Kopi Yang Tumbuh dibawah Naungan, Sebagus Apa? Retrieved August 29, 2019, from https://majalah.ottencoffee.co.id/kopiyang-tumbuh-di-bawah-naungan-pohonsebagus-apa/

Najiyati, S., \& Danarti. (1990). Kopi, Budidaya dan Penanganan Lepas Panen. Jakarta: Penebar Swadaya.

Pustaka Petani. (2018). Syarat Tumbuh Tanaman Karet. Retrieved August 29, 2019, from http://www.pustakapetani.com/2018/03/sy arat-tumbuh-tanaman-karet.html

Rachmat, R. K. (2007). Pengaruh Pengawetan terhadap Sifat Mekanis Tiga Jenis Kayu. Skripsi. Fakultas Kehutanan. Institut Pertanian Bogor.

Rochim, F. (2017). Eksplorasi Material Kayu Kopi Pada Produk Home Decor Dan Urban
Innovation Product. Tugas Akhir. Fakultas Teknik Sipil dan Perencanaan. Institut Teknologi Sepuluh November. Surabaya.

Suheryanto, D. (2010). Pengaruh Konsentrasi Cupri Sulfat terhadap Keawetan Kayu Karet. Seminar Rekayasa Kimia Dan Proses, E-06. Semarang: Jurusan Teknik Kimia, Fakultas Teknik, Universitas Diponegoro.

Suriani, E. (2018). Kajian Terhadap Variasi Metode dan Bahan Pengawet pada Proses Pengawetan Bambu-Kayu di Indonesia. EMARA: Indonesian Journal of Architecture, 4(1), 54-64. https://doi.org/10.29080/emara.v4i1.338

Wahyudi, I. (2013). Hubungan Struktur Anatomi Kayu dengan Sifat Jayu, Kegunaan dan Pengolahannya. In LitBang Anatomi Kayu Indonesia.

Wiratno, Nurhayati, H., \& Sujianto. (2019). Pemanfaatan Brotowali (Tinospora crispa) Sebagai Pestisida Nabati. Perspektif, 18(1), 28-39.

https://doi.org/10.21082/psp.v18n1.2019 
clKh Dinamika Kerajinan dan Batik: Majalah Ilmiah. Vol. 37 No. 2, Desember 2020, hal. 185 - 194 